\title{
Kemampuan Beberapa Tumbuhan Air dalam Menurunkan Pencemaran Bahan Organik dan Fosfat untuk Memperbaiki Kualitas Air
}

\section{Ability Aquatic Plants to Reduce Organic Matters and Phosphate Pollution for Improve Water Quality}

\author{
LISMINING PUJIYANI ASTUTI DAN INDRIATMOKO \\ Balai Riset Pemulihan Sumber Daya Ikan, Kementerian Kelautan dan Perikanan \\ lisminingastuti@gmail.com
}

\begin{abstract}
Aquatic plants are important part of aquatic ecosystem that can be used as an phytoremidiation agent, trapping organic matter in eutrophic waters as well as cleaning and controlling heavy metal pollution, pesticides and oil. The aim of research to assess the ability of some aquatic plants to organic matter and phosphate reduction for improve water quality. Research conducted at the Greenhouse of Institution Research for Fishes Resources Rehabilitation in May 2016. The study using factorial completely randomized and all treatment were conducted in triplicate. Aquatic plants are used Azolla sp., Spirodela sp., Duckweed (Lemna sp.), Salvinia sp., Water lettuce (Pistia sp), and water hyacinth (Eicchornia crassipes). Water media used are high stock solution of organic matter derived from fish farming waste water containing undigested, food, faeces and urine of fish. Water sampling was conducted on day $0\left(T_{0}\right), 2^{\text {nd }}\left(T_{2}\right), 5^{\text {th }}\left(T_{5}\right)$ and $9^{\text {th }}\left(T_{9}\right)$ after planting. The results showed that the total organic matter) and P-PO4 significantly different based on day of sampling, while the aquatic plant treatment significantly different at P-PO4 concentration, but not significantly different from the organic matter. However, based on the percentage change showed that the wood lettuce (Pistia $\mathrm{sp}$ ) capable of lowering the BOT and P-PO4 as much as 55.52\% and 60.62\%, and the water hyacinth can lower both BOT and P-PO4 as much as $23.38 \%$ and $92.68 \%$. Relative growth rate (RGR) was higher in the aquatic plants that tend to be small as Spirodela $s p$, Lemna $s p$ and with doubling time (DT) is relatively short. Water hyacinth plants tend to have a lower $R G R$ values and DT are relatively long. The value of $R G R$ and $D T$ related to the availability of nutrients.
\end{abstract}

Keywords: Aquatic Plants, Water Quality, Relative Growth Rate (RGR), Doubling Time (DT)

\begin{abstract}
ABSTRAK
Tumbuhan air merupakan bagian penting dari ekosistem perairan yang dimanfaatkan sebagai agen fitoremediasi, perangkap bahan organik di perairan eutrofik serta membersihkan dan mengontrol pencemaran logam berat, pestisida dan minyak. Tujuan penelitian untuk mengkaji kemampuan beberapa tumbuhan air dalam mengurangi pencemaran bahan organik dan fosfat dalam upaya memperbaiki kualitas perairan. Penelitian dilakukan di laboratorium rumah kaca Balai Riset Pemulihan Sumberdaya Ikan pada bulan Mei 2016. Penelitian menggunakan Rancangan Acak Lengkap Faktorial dengan tiga ulangan. Tumbuhan air yang digunakan Azolla sp., Spirodela sp., Mata lele (Lemna sp.), Kiambang (Salvinia sp.), Kayu apu (Pistia sp.), dan Eceng Gondok (Eicchornia crassipes). Media air yang digunakan adalah larutan stok tinggi bahan organik berasal dari air limbah budidaya ikan yang mengandung sisa pakan yang tidak tercerna, feses dan urin ikan. Pengambilan sampel air dilakukan pada 0 hari $\left(T_{0}\right), 2$ hari $\left(T_{2}\right), 5$ hari $\left(T_{5}\right)$ dan 9 hari $\left(T_{9}\right)$ setelah penanaman. Hasil penelitian menunjukkan bahwa bahan organik total (BOT) dan P-PO4 berbeda nyata pada perlakuan hari, sementara perlakuan jenis tumbuhan air berbeda nyata pada konsentrasi P-PO4 namun tidak berbeda nyata pada BOT. Persentase perubahan menunjukkan bahwa kayu apu mampu menurunkan BOT dan $\mathrm{P}_{-} \mathrm{PO}_{4}$ sebesar $55,52 \%$ dan $60,62 \%$ serta eceng gondok mampu menurunkan BOT dan $\mathrm{P}_{-} \mathrm{PO}_{4}$ sebesar $23,38 \%$ dan $92,68 \%$. Nilai relative growth rate (RGR) lebih tinggi pada tanaman air yang cenderung kecil seperti Lemna sp dan Spirodela sp dengan doubling time (DT) yang relatif pendek. Tanaman eceng gondok cenderung mempunyai nilai RGR rendah dan DT yang relatif lama. Besarnya nilai RGR dan DT berkaitan dengan ketersediaan nutrisi.
\end{abstract}

Kata kunci: Tumbuhan Air, Kualitas Air, Relative Growth Rate (RGR), Doubling Time (DT) 


\section{PENDAHULUAN}

\subsection{Latar Belakang}

Tumbuhan air adalah tumbuhan yang tumbuh di air atau sebagian besar siklus hidupnya di air dan merupakan salah satu bagian penting dari ekosistem perairan. Kehadiran tumbuhan air dalam jumlah tertentu/terbatas dan perkembangan populasinya terkendali akan membentuk mikrohabitat yang dibutuhkan oleh ikan sebagai tempat berlindung, mencari makan (feeding ground), memijah (spawning ground) dan mengasuh anakan (nursery ground).

Selain berfungsi menciptakan mikrohabitat bagi ikan, tumbuhan air juga dapat dimanfaatkan untuk memperbaiki kualitas perairan. Manfaat tumbuhan air sebagai agen pembersih lingkungan sudah tidak diragukan lagi, namun demikian apabila populasi tumbuhan air telah mengalami blooming akan menjadikannya sebagai gulma air. Tumbuhan air mempunyai kemampuan sebagai agent fitoremediasi, akumulator logam berat dan bio filter. Fitoremediasi didefinisikan sebagai pencucian polutan yang dimediasi oleh tumbuhan termasuk pepohonan, rerumputan dan tumbuhan air. Pencucian diartikan penghancuran, inaktivasi atau imobilisasi polutan menjadi bentuk yang tidak berbahaya ${ }^{(1)}$. Teknologi fitoremediasi ini mudah, murah dan memberikan efek negatif yang kecil. Bahkan teknologi ini dapat dimanfaatkan untuk lokasi KJA dengan memanfaatkan tumbuhan air yang dapat berfungsi sebagai pakan ikan sekaligus sebagai penyerap nutrien yang berlebih seperti jenis Lemna sp(2).

Tumbuhan air juga bermanfaat sebagai perangkap bahan organik pada perairan eutrofik serta mempunyai sifat luxury uptake yaitu mampu menyerap zat atau nutrisi tertentu melebihi kebutuhannya ${ }^{(3)}$. Tumbuhan air juga dapat berfungsi untuk membersihkan dan mengkontrol pencemaran oleh logam berat, pestisida dan minyak ${ }^{(4)}$. Eceng gondok (Eicchornia crassipes) mempunyai kemampuan dalam menyerap ion logam seperti cadmium $(\mathrm{Cd})$, timbal $(\mathrm{Pb})$ dan besi $(\mathrm{Fe})$, senyawa organik dari suatu larutan, menurunkan TSS dan

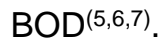

\subsection{Tujuan Penelitian}

Penelitian ini bertujuan untuk mengkaji kemampuan beberapa tumbuhan air untuk mengurangi bahan organik dan fosfat dalam upaya memperbaiki kualitas perairan.

\section{BAHAN DAN METODE}

\subsection{Pelaksanaan Penelitian}

Penelitian dilakukan di Laboratorium rumah kaca Balai Riset Pemulihan Sumberdaya Ikan pada bulan Mei 2016. Penelitian menggunakan Rancangan Acak Lengkap faktorial dengan tiga ulangan. Faktor dalam penelitian ini adalah jenis tumbuhan dan hari. Adapun langkah-langkah pelaksanaan penelitian adalah sebagai berikut:

1. Pembuatan larutan stok air tinggi bahan organik

Larutan stok tinggi bahan organik berasal dari air limbah budidaya ikan yang mengandung sisa pakan yang tidak tercerna, feses dan urin ikan. Pembuatan stok air limbah dengan pemeliharaan ikan sebanyak $3 \mathrm{~kg}$ ikan nila dalam kolam tertutup yang volumenya sekitar 1000 L. Ikan diberi pakan berupa pellet sebanyak $90 \mathrm{~g}$ per hari. Pemberian pakan dilakukan berturut-turut tanpa pemindahan sisa pakan dan feses ikan dari dasar kolam yang digunakan. Setelah air kelihatan keruh, berbau, berwarna hitam maka dilakukan uji kadar bahan organik total. Stok air tinggi bahan organik kemudian didistribusikan ke dalam 21 kolam kaca berdimensi $30 \times 30 \times 40 \mathrm{~cm}(\mathrm{p} \times \mathrm{I} \times \mathrm{t})$ masingmasing sebanyak $30 \mathrm{~L}$. Kolam kaca yang digunakan dilapisi plastik gelap untuk mencegah paparan cahaya matahari sehingga mengurangi potensi pertumbuhan alga.

\section{Penanaman tumbuhan air}

Pemilihan tumbuhan sebagai penyerap nutrien yang potensial berdasarkan kriteria yaitu (1) kecepatan tumbuh yng tinggi, (2) dapat memproduksi biomassa yang besar dalam luasan tertentu, (3) dapat menimbun nutrien yang banyak, (4) relatif mudah dipanen, (5) mempunyai kandungan nutrisi yang cukup untuk dimanfaatkan sebgai pakan dan pupuk(3). Berdasarkan hal tersebut maka, tumbuhan air yang terpilih untuk digunakan dalam penelitian ini meliputi Azolla sp., Spirodela sp., Mata lele (Lemna sp.), Kiambang (Salvinia sp.), Kayu apu (Pistia sp)., dan eceng gondok (Eicchornia crassipes). Tanaman yang akan digunakan dalam penelitian dibersihkan menggunakan air bersih mengalir untuk menghilangkan partikel pengotor dan alga yang memungkinkan berkontribusi dalam peningkatan bias data. Tanaman yang sudah dibersihkan kemudian di inisiasi dalam air bersih selama 3 hari sebelum di tempatkan di kolam kaca untuk pengujian. Setelah itu tumbuhan air ditempatkan ke kolam kaca dengan ulangan 3. Pengambilan sampel air dilakukan pada 0 hari (saat penanaman), 2, 5 
dan 9 hari setelah penanaman. Parameter kualitas air yang diamati adalah oksigen terlarut menggunakan Water quality chekcer, bahan organik total (BOT) dengan metode kalium permanganat dan $\mathrm{P}_{-} \mathrm{PO}_{4}$ dengan metode asam askorbat.

\subsection{Analisis Data}

Perhitungan relative growth rate $(\mathrm{RGR})^{(8,9)}$ untuk mengetahui laju pertumbuhan harian yang berdasarkan persamaan :

$R G R=\left(\ln M T_{2}-\ln M T_{1}\right) /\left(T_{2}-T_{1}\right)$

Perhitungan doubling time (DT) yaitu waktu yang dibutuhkan untuk menjadi dua kali lipat biomassanya ${ }^{(8,9)}$.

$D T=\ln 2 / R G R$.

Keterangan

RGR : relative growth rate ( $\mathrm{g} / \mathrm{hari})$

T : Waktu

$\mathrm{MT}_{1} \quad$ : $\quad$ biomassa pada saat $\mathrm{T}_{1}$

$\mathrm{MT}_{2} \quad$; biomassa pada saat $\mathrm{T}_{2}$

DT : Doubling time (hari)

Persentase perubahan

$\%$ perubahan $=\frac{\left(\mathrm{C}_{\text {awal }}-\mathrm{C}_{\text {akhir }}\right)}{\mathrm{C}_{\text {awal }}} \times 100$

Keterangan:

$\mathrm{C}_{\text {awal }} \quad: \quad$ konsentrasi awal sebelum perlakuan

$\mathrm{C}_{\text {akhir }} \quad$ : konsentrasi akhir sesudah perlakuan

Nilai (-) menunjukkan penurunan dan (+) menunjukkan peningkatan

Selanjutnya untuk mengetahui beda nyata perlakuan pada kualitas air pada masing-masing jenis tumbuhan air dan hari dianalisis dengan uji anova dengan tingkat kepercayaan 95\% dan dilanjutkan dengan uji Duncan Multiple range test (DMRT).

\section{HASIL DAN PEMBAHASAN}

\subsection{Kualitas Air $\left(\mathrm{O}_{2}, \mathrm{P}-\mathrm{PO}_{4}\right.$, Bahan Organik Total)}

Oksigen terlarut merupakan indikator pencemaran lingkungan perairan. Oksigen yang tinggi menandakan perairan yang baik, sebaliknya oksigen yang rendah menandakan adanya pencemaran perairan. Keberadaan oksigen terlarut sangat penting dalam ekosistem perairan untuk menunjang kehidupan organisme di dalamnya ${ }^{(10)}$.

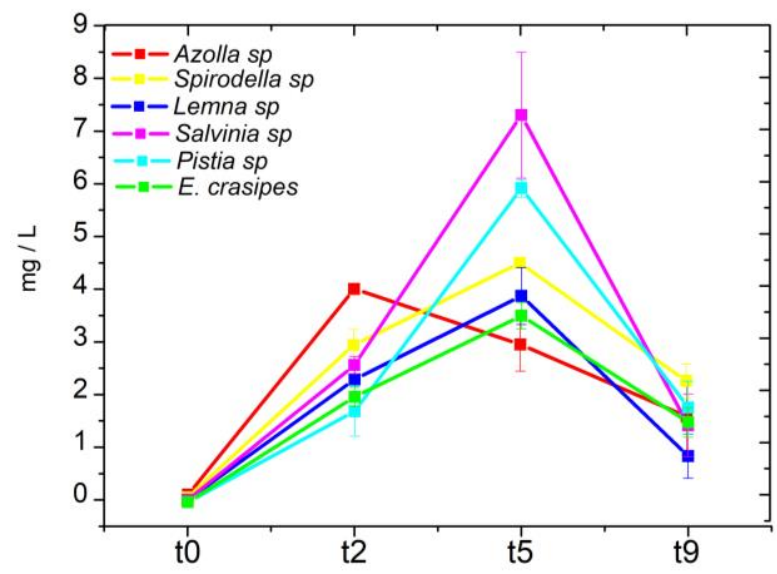

Gambar 1. Nilai DO air yang digunakan selama perlakuan

Pengamatan terhadap perubahan konsentrasi oksigen terlarut selama perlakuan menunjukan bahwa terjadi peningkatan nilai oksigen terlarut (DO) hingga titik optimum $\mathrm{T}_{5}$ untuk hampir semua tanaman air yang digunakan kecuali Azolla $s p$ yang mencapai titik optimum $\mathrm{DO}$ pada $\mathrm{T}_{2}$ (Gambar 1). Penurunan nilai DO diduga karena sebagian tumbuhan air telah menutupi perairan sehingga organisme kecil lainnya tidak mampu berfotosintesis. Tanaman air yang digunakan sebagai tumbuhan uji merupakan tumbuhan air mengapung sehingga produksi oksigen dari fotosintesisnya akan ke udara atmosfer. Dan juga ada sebagian biomassa dari tumbuhan air telah mati yang menyebabkan peningkatan bahan organik perairan. Pada pemanfaatan eceng gondok dan kayu apu mengalami peningkatan DO berturutturut $0,4-2,8 \mathrm{mg} / \mathrm{L}$ dan $1,0-2,6 \mathrm{mg} / \mathrm{L}^{(11)}$.

Pengamatan nilai bahan organik total (BOT) dalam penelitian ini menunjukan hasil yang bervariasi antar tanaman air yang digunakan. Masing-masing tanaman air menunjukan kemampuan yang berbeda dalam merespon bahan organik. Tumbuhan tidak secara langsung menyerap bahan organik namun tumbuhan air memberikan kondisi yang memungkinkan terjadinya proses dekomposisi bahan organik oleh mikroorganisme. Gambar 2 menunjukkan konsentrasi bahan organik pada media tanaman uji. Konsentrasi bahan organik meningkat pada perlakuan kontrol sedangkan tanaman Azolla sp dan Spirodela sp cenderung berfluktuasi dan pada $\mathrm{T}_{9}$ lebih tinggi dibanding $\mathrm{T}_{0}$. Terjadi peningkatan persentase perubahan BOT pada kolam kontrol (Gambar 3) dari kondisi awal ( $\left.T_{0}\right)$ hingga $T_{9}$. Hal ini menunjukan selama perlakuan, proses dekomposisi masih terus berlangsung. Terjadi fluktuasi peningkatan BOT pada $\mathrm{T}_{2}$ dan $\mathrm{T}_{5}$ pada tanaman uji Azolla sp. dan Spirodela sp.yang artinya bahwa tanaman tersebut kurang mampu berkontribusi secara 
signifikan untuk mengurangi total bahan organik. Diduga tanaman Azolla $\mathrm{sp}$ dan Spirodela $\mathrm{sp}$ berukuran relatif kecil dan pertumbuhan cepat $^{(28,29)}$, sehingga sebagaian tanaman yang mati menjadi sumber bahan organik perairan. Fenomena ini menunjukkan bahwa tanaman air berukuran kecil dan telah menutupi sebagian permukaan perairan akan menghambat proses dekomposisi bahan organik oleh mikroorganisme. Adanya perbedaan konsentrasi awal bahan organik ( $\mathrm{t}_{0}$ ) pada kisaran $15-30$ $\mathrm{mg} / \mathrm{L}$ diduga karena air limbah dari kolam ikan masih mengandung butiran sisa pakan yang yang merupakan sumber bahan organik dan belum terdekomposisi.

Penurunan persentase BOT dari nilai awal diketahui terjadi pada penggunaan tanaman Lemna sp., Salvinia sp., Pistia sp., dan Eicchornia crassipes. Namun demikian, diantara ke empat tanaman tersebut yang penurunannya paling tinggi adalah Pistia $s p(55,52 \%)$ kemudian Salvinia sp (29,35\%) yang lebih rendah dari $86,53 \%{ }^{(25)}$. dan Eicchornia crassipes $(23,38 \%)$ dan yang terakhir Lemna sp $(15,51 \%)$ sehingga Pistia sp dapat direkomendasikan sebagai tanaman air yang secara signifikan mampu mereduksi bahan organik dalam perairan. Pistia $\mathrm{sp}$ dapat menurunkan BOD limbah batik yaitu dari $582 \mathrm{mg} / \mathrm{L}$ menjadi $208 \mathrm{mg} / \mathrm{L}$ selama sembilan hari pengamatan (27). Eceng gondok mampu mengurangi pencemaran oleh zat organik $^{(12)}$. Penurunan BOD juga dapat disebabkan oleh proses fitodegradasi yaitu penyerapan kontaminan organik pada air limbah yang melewati rhizospere oleh akar dan mengalami penguraian melalui proses metabolik dalam tumbuhan ${ }^{(25)}$.

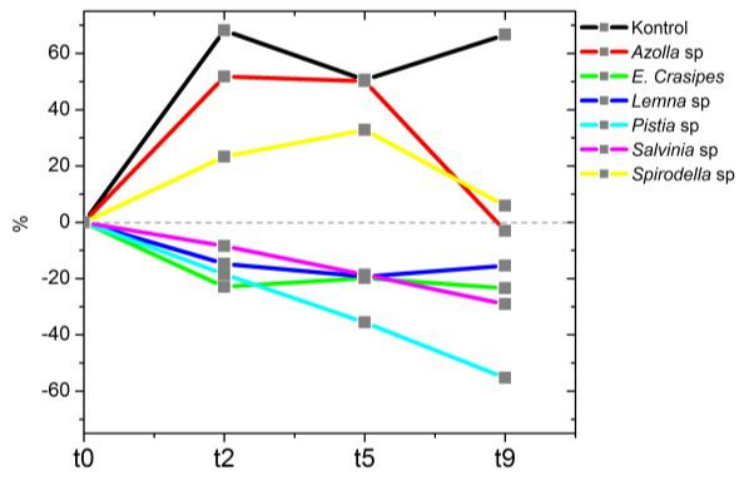

Gambar 2. Persentase perubahan bahan organik total

Secara alami, fosfat sendiri merupakan unsur hara yang sangat dibutuhkan bagi tanaman dalam pertumbuhan(13). Salah satu nutrien hasil dekomposisi bahan organik adalah $\mathrm{P}-\mathrm{PO}_{4}$. Konsentrasi $\mathrm{P}-\mathrm{PO}_{4}$ pada saat awal cukup tinggi mencapai $>2 \mathrm{mg} / \mathrm{L}$ yang menunjukkan perairan bersifat eutrofik. Tanaman eceng gondok mampu mengurangi $\mathrm{P}_{-} \mathrm{PO}_{4}$ hingga di bawah $0,25 \mathrm{mg} / \mathrm{L}$ (Gambar 4). Penurunan $\mathrm{P}_{-} \mathrm{PO}_{4}$ pada $\mathrm{T}_{9}$ tanaman eceng gondok mencapai $92,68 \%$ dan paling tinggi diantara tanaman uji lainnya kemudian Pistia sp mencapai 60,75\% (Gambar 5). Eceng gondok mampu mengurangi total fosfor hingga $98,5 \%$.(11). Efisiensi penurunan fosfor oleh eceng gondok berkisar $72-85 \%{ }^{(14)}$. Dalam $1 \mathrm{~kg}$ eceng gondok mampu menyerap 5,0 $\mathrm{mg} / \mathrm{L} \quad \mathrm{P}_{-} \mathrm{PO}_{4}{ }^{(15)}$. Ini berarti eceng gondok (Eicchornia crassipes) mempunyai kemampuan yang signifikan dalam mengurangi konsentrasi fosfat yang ada dalam perairan. Eceng gondok mampu menyerap logam berat, kontaminan organik dan nutrien dari kolom air(16). Pistia stratoites mampu menurunkan $\mathrm{P}_{-} \mathrm{PO}_{4}$ dari 47,5 $\mathrm{mg} / \mathrm{L}$ menjadi $12,4 \mathrm{mg} / \mathrm{L}$ selama 30 hari atau penurunannya sekitar $73,9 \%{ }^{(17)}$. Sementara tumbuhan Spirodela sp mampu menurunkan P$\mathrm{PO}_{4}$ sebesar $60,14 \%$ selama 9 hari dan jenis Spirodela oligorrhiza mampu menurunkan total fosfor limbah peternakan babi sebesar $89,4 \%$ setelah delapan minggu pemeliharaan pada kolam percobaan dengan media limbah ternak babi(18). Spirodela oligorrhiza merupakan jenis Spirodela yang tahan pada perairan bernutrisi tinggi, suhu rendah dan menghasilkan protein yang tinggi(18).

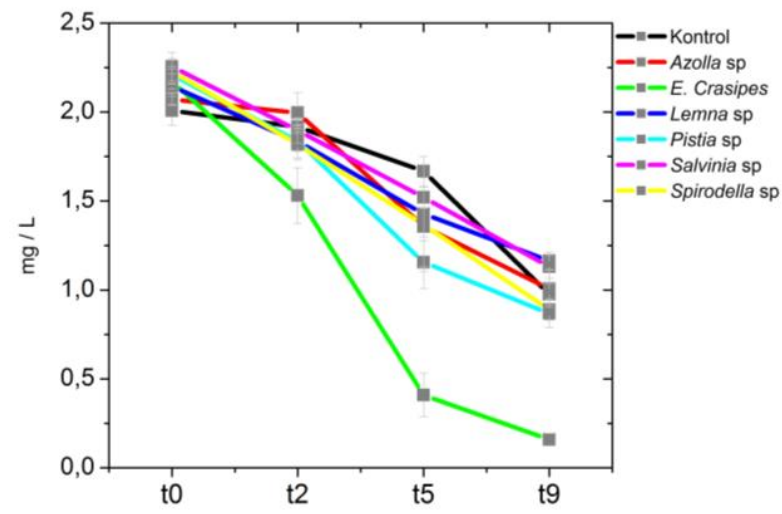

Gambar 3. Konsentrasi $\mathrm{P}-\mathrm{PO}_{4}$ selama penelitian

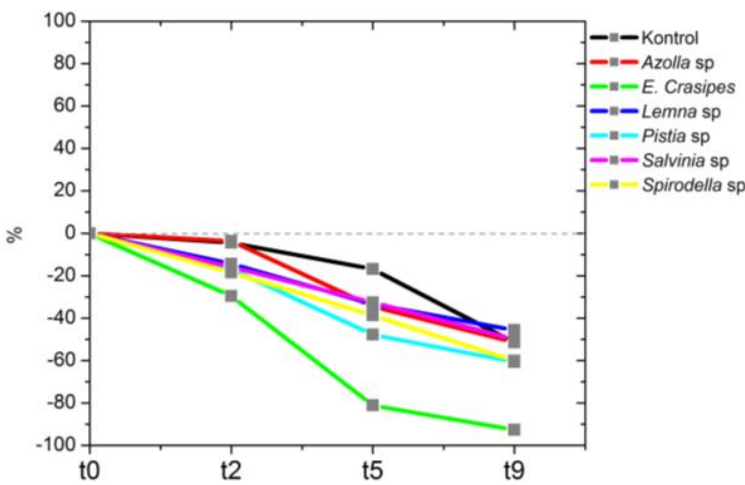

Gambar 4. Persentase perubahan $\mathrm{P}-\mathrm{PO}_{4}$ selama penelitian 
Hasil uji beda nyata perlakuan hari dan jenis tumbuhan menunjukkan bahwa perlakuan hari memberikan signifikasi yang nyata pada konsentrasi $\mathrm{P}_{-} \mathrm{PO}_{4}$ dan $\mathrm{BOT}$. Perlakuan hari terjadi perbedaan yang sangat nyata pada hari ke-9 (untuk $\mathrm{P}_{-} \mathrm{PO}_{4}$ dan BOT) dan berbeda nyata pada hari ke 5 untuk BOT (Tabel 1). Sementara perlakuan tumbuhan air memberikan signifikasi yang nyata pada konsentrasi $\mathrm{P}_{-} \mathrm{PO}_{4}$ namun tidak berbeda nyata pada konsentrasi BOT (Tabel 2). Pada $\mathrm{T}_{9}$ menunjukkan konsentrasi $\mathrm{P}_{-} \mathrm{PO}_{4}$ dan BOT dengan nilai terkecil dibandingkan pada $T_{0}$, $\mathrm{T}_{2}$ dan $\mathrm{T}_{5}$. Hal ini diduga bahwa semakin lama waktunya maka semakin terdekomposisi bahan organiknya sehingga BOT semakin kecil dan hasil dekomposisi telah dimanfaatkan oleh tumbuhan sehingga $\mathrm{P}_{-} \mathrm{PO}_{4}$ juga semakin kecil. Perlakuan tumbuhan air menunjukkan bahwa konsentrasi $\mathrm{P}_{-} \mathrm{PO}_{4}$ pada jenis eceng gondok berbeda sangat nyata dengan tumbuhan uji lainnya. Ini menunjukkan jenis eceng gondok mampu menyerap $\mathrm{P}_{-} \mathrm{PO}_{4}$ lebih baik dibanding tumbuhan uji lainnya.

Tabel 1. Hasil uji DMRT perlakuan hari

\begin{tabular}{llll}
\hline No & Hari & ${\mathrm{P}-\mathrm{PO}_{4}}$ & $\mathrm{BOT}$ \\
\hline 1 & 0 & $2,156^{\mathrm{b}}$ & $27,455^{\mathrm{b}}$ \\
2 & 2 & $1,833^{\mathrm{b}}$ & $26,879^{\mathrm{b}}$ \\
3 & 5 & $1,273^{\mathrm{b}}$ & $26,158^{\mathrm{ab}}$ \\
4 & 9 & $0,884^{\mathrm{a}}$ & $23,667^{\mathrm{a}}$ \\
\hline
\end{tabular}

Keterangan: huruf yang sama menunjukkan tidak ada beda nyata pada uji DMRT 5\%

Tabel 2. Hasil uji DMRT perlakuan tumbuhan air

\begin{tabular}{lll}
\hline No & Tumbuhan air & $\mathrm{P}^{-\mathrm{PO}_{4}}$ \\
\hline 1 & Kontrol & $1,642^{\mathrm{b}}$ \\
2 & Eicchornia crassipes & $1,068^{\mathrm{a}}$ \\
3 & Salvinia sp & $1,705^{\mathrm{b}}$ \\
4 & Pistia sp & $1,517^{\mathrm{b}}$ \\
5 & Lemna sp & $1,643^{\mathrm{b}}$ \\
6 & Azolla sp & $1,608^{\mathrm{b}}$ \\
7 & Spirodela sp & $1,576^{\mathrm{b}}$ \\
\hline
\end{tabular}

Keterangan: huruf yang sama menunjukkan tidak ada beda nyata pada uji DMRT 5\%

Berdasarkan persentase perubahan dan hasil uji Anova dan DMRT menunjukkan bahwa jenis Pistia sp mampu menurunkan bahan organik dengan persentase $55,52 \%$ dan $\mathrm{P}_{-} \mathrm{PO}_{4}$ sebesar 60,62\%; eceng gondok mampu menurunkan $\mathrm{P}_{-} \mathrm{PO}_{4}$ sebesar $92,68 \%$ selama 9 hari serta berbeda nyata dengan tanaman uji lainnya maka jenis eceng gondok dan Pistia sp dapat direkomendasikan menjadi tumbuhan air yang mampu memperbaiki kualitas air. Pistia sp dapat menurunkan orthofosfat limbah deterjen sebesar $15,35 \%$ pada hari ke $6^{(26)}$ dan $39,5 \%$ selama 14 hari(30) dan ini lebih rendah dari hasil penelitian ini yang mencapai $40 \%$ pada hari ke lima. Perbedaan ini diduga karena konsentrasi orthofosfat awal lebih tinggi penelitian ini yaitu >
$2 \mathrm{mg} / \mathrm{L}$. Tanaman genjer (Limnocharis flava L) mampu menurunkan konsentrasi fosfat limbah deterjen sebesar $31,8 \%$ selama 14 hari yaitu dari konsentrasi 2,90 $\mathrm{mg} / \mathrm{L}$ menjadi 1,98 $\mathrm{mg} / \mathrm{L}(30)$. Kondisi akar, morfologi tanaman yang baik dan nilai $\mathrm{pH}$ perairan berpengaruh pada penyerapan fosfat ${ }^{26,30)}$. $\mathrm{pH}$ yang baik untuk penyerapan fosfat adalah $6-7$, apabila nilai $\mathrm{pH}$ lebih tinggi ataupun lebih rendah dari nilai 6-7 maka penyerapan $\mathrm{P}$ dapat terganggu( ${ }^{(30)}$.

\section{Pertumbuhan Tanaman}

Pertumbuhan tanaman air yang digunakan selama penelitian ini dihitung berdasarkan biomasa (g) pada kondisi awal $\left(\mathrm{T}_{0}\right)$ hingga $\mathrm{T}_{9}$.

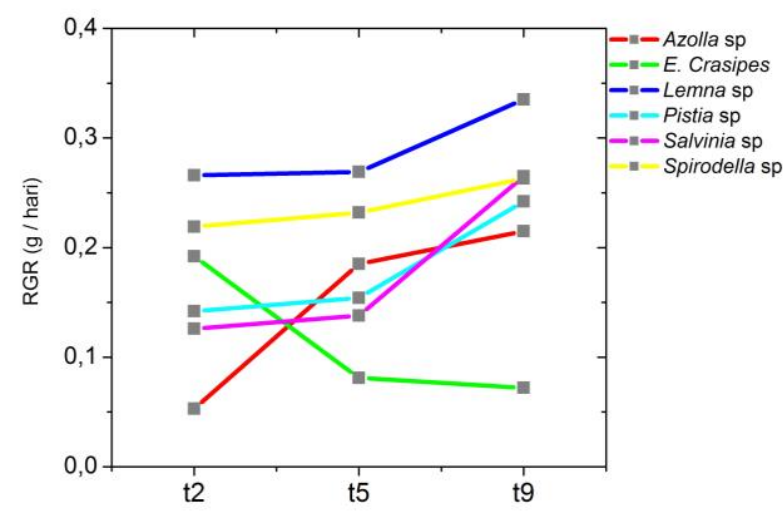

Gambar 6. Besarnya nilai relative growth rate (RGR) tumbuhan air uji

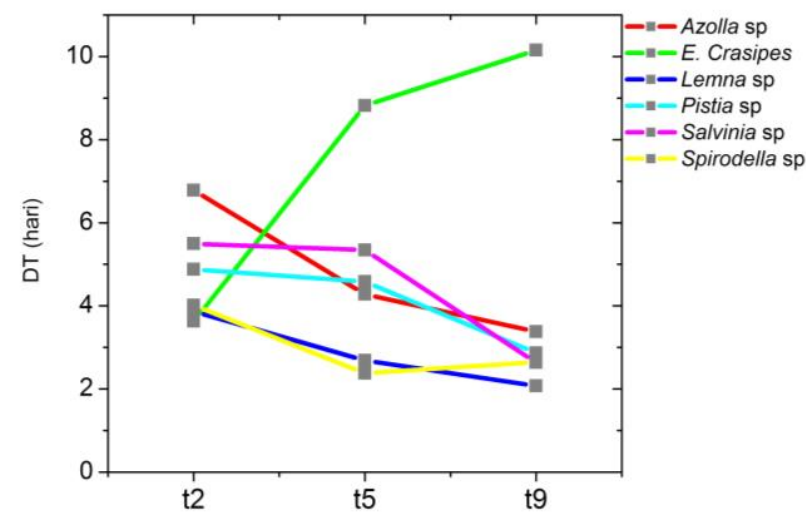

Gambar 7. Doubling time (DT) tumbuhan air uji

Secara umum, laju pertumbuhan relatif (RGR) tanaman uji mengalami peningkatan kecuali eceng gondok (Gambar 6). Perlambatan pertumbuhan pada tanaman pada umumnya berkorelasi positif terhadap menurunnya asupan nutrisi pada media tanam yang dalam penelitian ini adalah air media yang digunakan ${ }^{(19)}$. Hal tersebut juga menunjukan kecepatan serap tanaman dalam menyerap nutrisi dalam air. Nilai RGR yang tinggi menunjukan kemampuan tumbuh yang besar masing-masing tanaman selama perlakuan. Nilai RGR yang tinggi pada 
tanaman Lemna sp, Spirodela sp, dan Salvinia sp. Salvinia sp merupakan jenis tumbuhan air yang dapat tumbuh baik apabila didukung dengan intensitas cahaya tinggi, suhu lebih tinggi dan kecukupan nutrien terutama nitrogen dan fosfor. Kondisi eutrofik yang kaya akan nutrient dapat mempercepat pertumbuhan dan kolonisasi(20). Besarnya nilai doubling time (DT) secara umum menurun, kecuali eceng gondok (Gambar 7), yang diduga berkaitan dengan ketersediaan nutrisi.

Azolla sp merupakan tumbuhan air mengapung, ukuran daun kecil, tersebar di daerah tropis dan sub tropis. Pertumbuhan Azolla sp termasuk cepat dengan doubling time (DT) berkisar 2 - 5 hari(21); 4,9 hari(22) dan nilai selama penelitian berkisar 3,3-6,7 hari. Peningkatan fosfor dan kerapatan tumbuhan dapat mengakibatkan peningkatan sporulasi yaitu pembentukan spora pada sel induk yang akhirnya spora berkembang menjadi individu baru. Konsentrasi fosfor 0,06 ppm cukup untuk pertumbuhan Azolla sp secara sustain di laboratorium, namun di lapangan membutuhkan fosfor $0,3-1 \mathrm{ppm}(21)$. Konsentrasi $\mathrm{P}_{-} \mathrm{PO}_{4}$ pada $\mathrm{T}_{9}$ sekitar $1 \mathrm{mg} / \mathrm{L}$ sehingga cukup untuk pertumbuhan Azolla sp.

Lemna sp merupakan tumbuhan air monokotil yang kecil, bunga sangat sederhana pertumbuhan cepat, serta mengapung bebas di perairan air tawar dan menjadi tanaman indikator untuk mengkaji pencemaran perairan ${ }^{(2,18)}$. Nilai RGR Lemna sp berkisar 0,266 - 0,335 dengan DT berkisar 2,1 - 3,9 hari dan tidak jauh berbeda dari nilai RGR berkisar 0,153 - 0,539 $\mathrm{g} /$ hari dengan DT berkisar $1,34-4,54$ hari ${ }^{(18)}$ dan nilai DT hampir sama dengan 3,8 hari(22). Jenis Spirodela sp mempunyai nilai DT berkisar 2,4 4,0 hari tidak jauh beda dari nilai 2,7 hari(22).

Laju pertumbuhan spesifik eceng gondok di delta Sungai Nil pada bulan April - Mei adalah $0,004 \mathrm{~g} / \mathrm{hari}$ dengan total biomassa $196-960$ $\mathrm{g} / \mathrm{m}^{2}$ dan menurun menjadi $0,001 \mathrm{~g} /$ hari ketika terjadi peningkatan total biomassa menjadi 1088 $\mathrm{g} / \mathrm{m}^{2}$. Rendahnya laju pertumbuhan relatif eceng gondok pada saat terjadi peningkatan biomassa diduga karena adanya naungan sendiri akibat padat atau terjadi kompetisi intraspesifik untuk cahaya dan ruang. Pertumbuhan eceng gondok dipengaruhi oleh ketersediaan nutrien, kerapatan tanaman, cahaya dan musim. Penelitian di Chiba, Jepang menunjukkan bahwa eceng gondok mempunyai nilai RGR lima kali lebih besar dan nilai DT empat kali lebih cepat dimusim panas daripada musim dingin ${ }^{(23)}$. Selain itu penambahan pupuk dapat meningkatkan kesuburan sehingga meningkatkan nilai RGR menjadi delapan kali lebih tinggi dan nilai DT menjadi lima kali lebih pendek. Beberapa nilai DT eceng gondok berkisar antara $10-64$ hari di bendungan di Mexico(24); sekitar 13,8 hari(22) dan hasil penelitian ini berkisar 3,6 - 10,15 hari.

Tumbuhan air mengapung yang kecil seperti Azolla, Lemna, Pistia dan Spirodela mempunyai doubling time yang lebih kecil atau sama dengan jenis Egeria densa sebesar 5-12 hari, Egeria najas sebesar 7 - 27 hari dan Ceratophyllum demersum sebesar 15 - 51 hari Keuntungan tumbuhan air mengapung adalah cahaya tidak menjadi faktor pembatas sementara untuk tumbuhan air sub merged terdapat efek naungan(22). Beberapa nilai RGR dan DT dari beberapa penelitian yang dirangkum oleh Pistori et al (2004) tersaji pada Tabel 3. Nilai RGR Salvinia sp selama penelitian berkisar 0,126 $0,265 \mathrm{~g} /$ hari. Nilai DT Salvinia sp adalah 2,6 - 5,5 hari yang tidak jauh berbeda dengan nilai 5,9 hari(22) dan lebih cepat dibanding hasil laboratorium(8). Nilai RGR Pistia $\mathrm{sp}$ berkisar $0,142-0,242 \mathrm{~g} / \mathrm{hari}$ lebih besar dibanding hasil laboratorium ${ }^{(8)}$. Nilai DT Pistia sp berkisar 2,9 4,9 hari dan lebih cepat dibanding hasil laboratorium ${ }^{(8)}$.

Tabel 3. Nilai RGR dan DT beberapa tumbuhan air(8)

\begin{tabular}{|c|c|c|c|c|c|}
\hline No & Tumbuhan air & RGR & DT & Keterangan & Referensi \\
\hline 1 & Salvinia molesta & 0,059 & 8,6 & Lapangan & Michell \& Tur (1975) \\
\hline 2 & Salvinia molesta & 0,5 & 1,4 & Lapangan & Finiayson (1984) \\
\hline 3 & Salvinia molesta & $0,20-0,11$ & $3,5-7,1$ & Lapangan & Rubim \& Camargo (2001) \\
\hline 4 & Salvinia molesta & $0,07-0,01$ & $9,9-69,3$ & Laboratorium & $\begin{array}{l}\text { Usha Rani \& Bhambie } \\
\text { (1983) }\end{array}$ \\
\hline 5 & Salvinia molesta & $0,031-0,01$ & $22,4-69,3$ & Laboratorium & Henry-Silva et al.(2002) \\
\hline 6 & Eicchornia crassipes & $0,025-0$ & 27,7 & Laboratorium & Henry-Silva et al.(2002) \\
\hline 7 & Eicchornia crassipes & $0,06-0,01$ & $11,6-69,3$ & Laboratorium & Reddy \& DeBusk (1984) \\
\hline 8 & Pistia stratoites & $0,18-0,003$ & $3,9-231$ & Laboratorium & Reddy \& DeBusk (1984) \\
\hline 9 & Pistia stratoites & $0,031-0$ & 22,4 & Laboratorium & Henry-Silva et al.(2002) \\
\hline 10 & Egeria densa & $0,063-0,009$ & $12-194$ & Laboratorium & Pistori et al. (2004) \\
\hline
\end{tabular}




\section{KESIMPULAN}

Tumbuhan air mempunyai manfaat sebagai fitoremediator untuk perbaikan lingkungan perairan. Kemampuan kayu apu (Pistia sp) dan eceng gondok (Eicchornia crassipes) dalam menurunkan bahan organik total secara berturutturut sebesar $55,52 \%$ dan $23,38 \%$ serta penurunan $\mathrm{P}_{-}-\mathrm{PO}_{4}$ sebesar $60,62 \%$ dan $92,68 \%$ lebih tinggi dari kemampuan Salvinia sp, Lemma $\mathrm{sp}$ dan Spirodela $\mathrm{sp}$. Nilai relative growth rate (RGR) lebih tinggi pada tanaman air yang cenderung kecil seperti Lemna sp dan Spirodela sp dengan doubling time (DT) yang relatif pendek. Tanaman eceng gondok cenderung mempunyai nilai RGR rendah dan DT yang relatif lama. Besarnya nilai RGR dan DT berkaitan dengan ketersediaan nutrisi. Berdasarkan penelitian ini, tumbuhan air yang efektif menurunkan bahan organik dan fosfat perairan adalah kayu apu dan eceng gondok.

\section{PERSANTUNAN}

Tulisan ini merupakan hasil dari kegiatan Penelitian Pemulihan Populasi dan Rehabilitasi Habitat Sumber Daya Ikan, Daya Dukung dan Daya Pulih Perairan di Daerah Aliran Sungai (DAS) Citarum pada sub kegiatan Penelitian Uji Serap Polutan Organik oleh Bahan Aktif Tanaman Air, Pengendalian Eceng Gondok dan Uji Kelayakan Smart KJA tahun anggaran 2016.

\section{DAFTAR PUSTAKA}

1. Hidayati, N. 2005. Fitoremediasi dan Potensi Tumbuhan Hiperakumulator (Phytoremediation and Potency of Hyperaccumulator Plants). Hayati 12 (1) : 35 $-40$.

2. Umarudin, J. Nur, A. Wulandari, M. Izzati. 2015. Efektivitas Tanaman Lemna (Lemna perpusilla Torr) Sebagai Agen Fitoremediasi Pada Keramba Jaring Apung (KJA) Disekitar Tanjungmas Semarang. Bioma 17 (1): 1-8.

3. Erlania. 2010. Pengendalian limbah budidaya perikanan melalui pemanfaatan tumbuhan air dengan sistem constructed wetland. Media Akuakultur Vol 5 (2): 129137.

4. Zhanga, B.Y., J.S. Zhenga, R.G. Sharp. 2010. Phytoremediation in Engineered Wetlands: Mechanisms and Applications. International Society for Environmental Information Sciences 2010 Annual Conference (ISEIS). Proceedia Environmental Sciences 2 : 1315- 1325
5. Haider, S.Z. Malik, K.M.A, and Rahman, M.M. (1984). Mechanism of absorption of chemical species from aqualons medium by water hyacinth and prospects of its utilization. Proceedings of $10^{\text {th }}$ International Conference on Water Hyacinth. Hyderabad, India: 7-11.

6. Ajayi, Tolu Olufunmilayo dan Atoke Olaide Ogunbayo. 2012. Achieving Environmental Sustainability In Wastewater Treatment By Phytoremediation With Water Hyacinth (Eicchornia Crassipes). Journal of Sustainable Development 5 (7).

7. Indrasti, Nastiti Siswi., Suprihatin, Burhanudin dan Aida Novita. 2006. Penyerapan Logam Pb Dan Cd Oleh Eceng Gondok: Pengaruh Konsentrasi Logam Dan Lama Waktu Kontak. J. Tek. Ind. Pert. 16(1) : 44-50

8. Pistori, RETI., Camargo, Henry Silva. 2004. Relative Growth Rate and Doubling Time of the Submerged Aquatic Macrophyte Egeria densa Planch. Acta Limnol. Bras. 16 (1): 7784

9. Zhou, X., G. Wang, $F$ Yang. 2011. Characteristics of growth, nutrient uptake, purification effect of Ipomoea aquatica, Lolium multiflorum, and Sorghum sudanense grown under different nitrogen levels. Desalination 273 : 366-374

10. Davis, J.C. 1975. Minimal dissolved oxygen requirements of aquatic life with emphasis on Canadian species: a review. Journal of the Fisheries Board of Canada 32, 22952332

11. Sooknah, RD., AC Wilkie. 2004. Nutrient removal by floating aquatic macrophytes cultured in anaerobically digested flushed dairy manure wastewater. Ecological Engineering 22: 27-42

12. Ratnani, RD., I. Hartati. L. Kurniasari. 2011. Pemanfaatan eceng gondok (Eicchorrnia crassipes) untuk menurunkan kandungan COD (Chemical Oxygen Demand), pH, bau, dan warna pada limbah cair tahu. Momentum 7(1) : 41 - 47

13. Minardi, S. 2013. Kajian Terhadap Pengaturan Pemberian Air Dan Dosis Tsp Dalam Mempengaruhi Keragaan Tanaman Jagung (Zea mays. L.) Di Tanah Vertisol. Sains Tanah-Journal of Soil Science and Agroclimatology, 2(1): 35-40

14. Kutty, SRM., SNI Ngatenah, MH Isa, A. Malakahmad. 2009. Nutrients Removal from Municipal Wastewater Treatment Plant Effluent using Eichhornia crassipes. World 
Academy of Science, Engineering and Technology International. Journal of Environmental, Chemical, Ecological, Geological and Geophysical Engineering 3 (12): 414- 419

15. Wang, H., H. Zhang, G. Cai. 2011. An application of phytoremidiation to River pollution remidiation. Procedia Enviromental Sciences: 3rd International Conterence on Environmental Science and information Application Technology (ESIAT 2011) 10:1904-1907.

16. Villamagna, AM and BR. Murphy. 2010. Ecological and socio-economic impacts of invasive water hyacinth (Eicchornia crassipes): a review . Freshwater Biology 55: 282-298.

17. Fonkou, T, P Agendia, I. Kengne, A Akoa and J Nya. 2002. Potentials of water lettuce (Pistia stratiotes) in domestic sewage treatment with macrophytic lagoon systems in Cameroon. Proceedings of International Symposium on Environmental Pollution Control and Waste Management (EPCOWM'2002) :709-714.

18. Xu, J., G. Shen . 2011. Growing duckweed in swine wastewater for nutrient recovery and biomass production. Bioresource Technology 102 : 848-853.

19. Agren, G.I., 2008. Stoichiometry and nutrition of plant growth in natural communities. Annual review of ecology, evolution, and systematics, 153-170.

20. Oliver, JD. 1993. A Review of the Biology of Giant Salvinia (Salvinia molesta Mitchell). J. Aquat. Plant Manage 31: 227-231.

21. Sadeghi, R., R. Zarkami, K. Sabetraftar, P. Van Damme. 2013. A review of some ecological factors affecting the growth of Azolla spp. Caspian J. Env. Sci. 2013, Vol. 11 (1): 65 76.

22. Bianchini Jr, I., MB Cunha-santino, JAM Milan, CJ Rodrigues, JHP Dias. 2015. Model parameterization for the growth of three submerged aquatic macrophytes. J. Aquat. Plant Manage 53: 64-73.

23. Eid, EM., and KH. Shaltout. 2016. Population dynamics of Eichhornia crassipes (C. Mart.) Solms in the Nile Delta, Egypt. Plant Species Biology : 1-12 doi: 10.1111/1442-1984.12154.

24. Gutiérrez, E.L., E.F. Ruiz, E.G. Uribe, J.M. Martínez. 2001. Biomass and Productivity of Water Hyacinth and Their Application in Control Programs. Biological and Integrated control of water hyacinth, Eicchornia crassipes. ACIAR Proceeding 102. 109 119.

25. Rahmawati, A., B. Zaman, Purwono. 2016. Kemampuan tanaman kiambang (Salvinia molesta) dalam menyisihkan bod dan fosfat pada limbah domestik (grey water) dengan sistem fitoremediasi secara kontinyu. Jurnal Teknik Lingkungan Vol. 5 (4) : 1-10.

26. Dewi, R.K, WR Melani, A. Zulfikar. 2018. Efektivitas dan efisiensi fitoremediasi orthofosfat pada deterjen menggunakan kiambang (Pistia stratiotes). jurnal.umrah.ac.id. 1-10 diakses 2 Maret 2018

27. Hernayanti \& E. Proklamasiningsih. 2008. Fitoremediasi limbah cair batik menggunakan kayu apu (Pistia stratiotes I.) Sebagai upaya untuk memperbaiki kualitas air. Jurnal Pembangunan Pedesaan Vol. IV (3):165 - 172.

28. Sudjana, B. 2014. Pengunaan Azolla untuk pertanian berkelanjutan. Jurnal IImiah Solusi Vol. 1 (2): $72-81$.

29. Bahri, S. 2010. Fitoremediasi timbal (Pb) dalam air tercemar oleh tumbuhan air great duckweed (Spirodela polyrhiza). Jurnal Teknik Hidraulik Vol. 6 (2): 95 - 192

30. Hermawati, E., Wiryanto, Solichatun. 2005. Fitoremediasi Limbah Detergen Menggunakan Kayu Apu (Pistia stratiotes L. ) dan Genjer (Limnocharis flava L.). BioSMART 7(2): 115-1. 